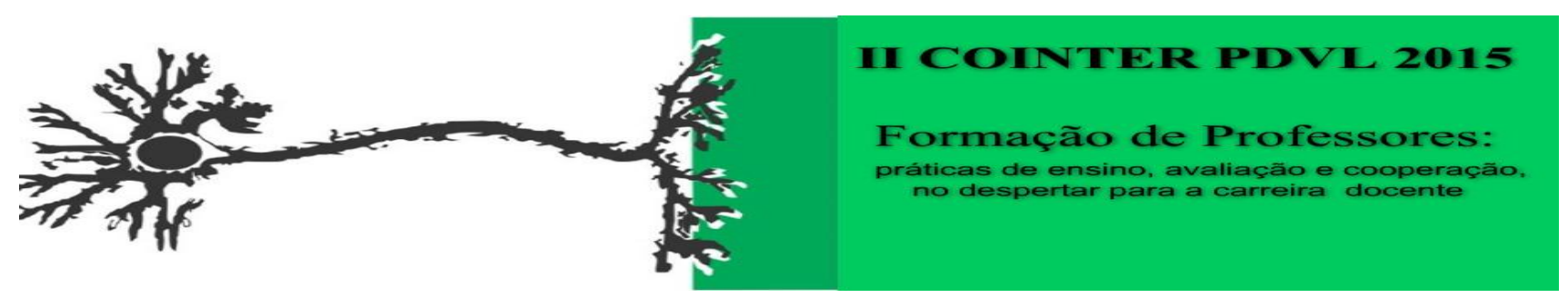

\title{
PROJETO PIBID: UM RELATO DE EXPERIÊNCIA SOBRE BRINQUEDOS FABRICADOS COM MATERIAIS RECICLADOS.
}

\author{
Apresentação: Relato de Experiência \\ Sandrielly do Prado Juvencio ${ }^{1}$; Gleice Kelly Alves de Morais ${ }^{2}$; Daniele Luiz da Silva ${ }^{3}$; \\ Levi Rodrigues de Miranda ${ }^{4}$
}

\section{Introdução}

O presente trabalho apresenta brevemente a experiência dos bolsistas PIBID - 2013, na Escola Estadual Nestor Lima, sobre a atividade realizada com os alunos do $7^{\circ}$ ano do Ensino Fundamental II. A experiência envolve o tema "Reciclagem", tendo com objetivo sensibilizar os alunos sobre a importância de reciclar, embasado na sustentabilidade e na educação ambiental.

\section{Relato de Experiência}

As questões ambientais nos dias atuais são discutidas em todo mundo e como intuito de aprofundar o conhecimento dos alunos sobre a questão da sustentabilidade, elaboramos uma aula expositiva dialogada sobre o tema. Após essa explanação sobre a temática, elaboramos uma oficina de brinquedos fabricados a partir de materiais recicláveis, para que os alunos compreendam a importância da temática e contribuam com a preservação do meio ambiente. Desta forma, solicitamos que os alunos ficassem a votante para levar os materiais para criar seus brinquedos que posteriormente ficariam expostos no laboratório de Geografia.

Assim, para o desenvolvimento da oficina foram necessários materiais como: garrafas PET, tampinhas, caixas de papelão, cola, tesoura, canetas coloridas, tinta guache, pincéis entre outros. Os alunos se responsabilizaram de levar os materiais recicláveis para construção dos brinquedos. Em sala de aula demonstramos como seria a confecção das peças. No desenvolvimento da oficina passamos para os alunos a importância da utilização do material reciclável.

\footnotetext{
${ }^{1}$ Licenciatura em geografia, IFRN, sandrielly.juvencio@hotmail.com

${ }^{2}$ Licenciatura em geografia, IFRN gleicekellybiologa@hotmail.com

${ }^{3}$ Licenciatura em geografia, IFRN, daniele.luiz@outlook.com

${ }^{4}$ Geografo, Mestre em arquitetura e urbanismo, docente IFRN, levi.miranda@ifrn.edu.br
} 
Imagem 1: Atividade Experimental. Fonte: Própria

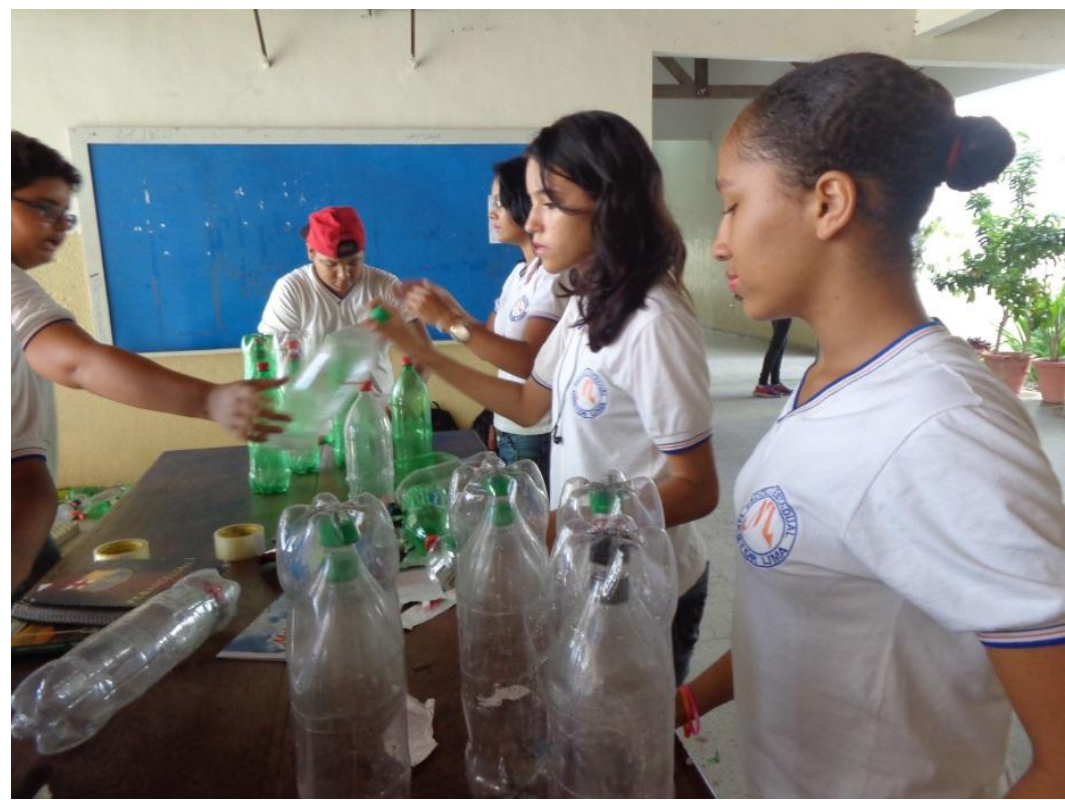

\section{Considerações}

Entre os resultados obtidos podemos destacar a empolgação dos alunos em participar da oficina e o interesse dos mesmos quanto a repassar a informação de que do lixo é possível se retirar muitas coisas interessantes como brinquedos para as crianças que hoje não possuem.

Assim, percebemos a tamanha importância dessa temática trabalhada pelos bolsistas do PIBID a fim de sensibilizar os alunos em relação às problemáticas ambientais existentes em seu entorno e no mundo, que acontecem muitas vezes por falta de informação das pessoas.

\section{Referências}
Meio
Ambiente
e Sustentabilidade.
disponível
em:
http://www.ecologiaurbana.com.br/conscientizacao/meio-ambiente-sustentabilidade/ acesso em: 25/10/15. 